\title{
Automation, Occupational Earnings Trends, and the Moderating Role of Organized Labor
}

\author{
Zachary Parolin \\ Columbia University \\ zachary.parolin@columbia.edu
}

\begin{abstract}
Routine-biased technological change has emerged as the dominant explanation for the differential earnings growth of occupations at greater risk of automation, such as machine operators or office clerks, relative to less routine occupations. In contrast, this paper finds that the declining earnings returns to an occupation's routine task intensity (RTI) can largely be attributed to the decline of organized labor. Using individual-level data on 3.3 million employed adults across the 50 United States from 1983-2017, this paper finds that organized labor has two countervailing effects on occupations at greater risk of automation. First, higher union coverage within a state and industry inhibits the decline in earnings returns to an occupation's RTI. Second, higher union coverage hastens the decline in employment shares of occupations with higher RTI. The result is that occupations at greater risk of automation experience more favorable earnings growth where unions are more resilient, but at the cost of accelerated declines in their employment shares. Counterfactual analyses demonstrate that if union coverage in the U.S. had remained stable at 1983 levels, the earnings returns to an occupation's RTI might not have declined from 1983-2017, and the observed pattern of occupational earnings polarization in the 1990s might not have occurred. However, the mean RTI of occupations might have declined by an additional 21 percent from 1983-2017 relative to the observed decline. The findings suggest that the social consequences of automation are conditional on the strength of organized labor.
\end{abstract}

Acknowledgments: This paper was completed as part of an OECD Future of Work Fellowship. For helpful comments and suggestions, I am grateful to Andrea Salvatori, Stijn Broecke, Diego Collado, Andrew Green, Dario Guarascio, Wim Van Lancker, Brian Nolan, Jose Pacas, Linus Sioland, and four anonymous reviewers. I also appreciate the feedback of participants at the 2018 ESPANet Conference in Vilnius, the "What drives inequality?" workshop in Luxembourg, the Herman Deleeck Centre for Social Policy Lunch Seminar series, the "Labor Market Liberalization after the Lehman Crisis" workshop in Tokyo, and the 2019 SASE Annual Meeting. 


\section{INTRODUCTION}

The effect of technological progress on the structure of employment and earnings has emerged as a central concern of labor market research. A dominant perspective in recent literature holds that advancements in technology contribute to differential earnings and employment growth in routine occupations, such as machine operators or office clerks, relative to less routine occupations, such as managers or service workers. Indeed, evidence suggests that declining demand for routine tasks has contributed to declining employment shares of automatable occupations across a broad range of advanced economies (Goos, Manning and Salomons 2014). With respect to earnings growth, however the story is mixed. During the 1990s, the earnings of automatable occupations in the U.S. grew at a slower rate than less routine occupations at the bottom and top of the wage distribution (Autor and Dorn 2013a, Mishel, Schmitt and Shierholz 2013). Outside of the U.S., however, this pattern of occupational earnings polarization has generally not been observed (Naticchioni, Ragusa and Massari 2014). In fact, earnings growth of automatable occupations continues to outpace that of low-routine, low-pay occupations in many advanced economies.

One defining difference of European and American labor markets is the strength of organized labor. While prior work has demonstrated that organized labor plays a central role in compressing the earnings distribution and increasing labor's share of national income (e.g. Brady, Baker and Finnigan (2013), Kristal (2013), Western and Rosenfeld (2011)), it remains unclear the extent to which declining worker power can explain patterns of occupational earnings polarization. This study investigates how labor unions moderate the effect of technological change on the relative earnings growth of occupations with higher routine task intensity (RTI). To do so, I apply Autor and Dorn's (2013) task composition data to a crossstate U.S. sample of 3.3 million employed adults using the U.S. Current Population Survey's Merged Outgoing Rotation Groups (CPS MORG). 
In contrast to the structural and macroeconomic explanations of occupational earnings trends, which ascribe changes in relative earnings growth of automatable occupations to exogenous shifts in the demand for routine tasks (Acemoglu and Autor 2011, Autor, Levy and Murnane 2003, Autor and Dorn 2013a), I posit that earnings and employment trends among occupations at greater risk of automation are conditional on the strength of organized labor. Specifically, I investigate the existence of an earnings effect, in which higher union membership within a state-industry inhibits declining earnings returns to an occupation's RTI. I also investigate the possibility of an employment share effect, in which union members can protect the earnings growth of high RTI occupations, but at the cost of an accelerated decline in employment shares among such occupations. The existence of these two countervailing effects would suggest that the strength of organized labor shapes patterns of occupational earnings and employment polarization, two phenomena that have been central to emergent literature on automation and technological change.

Findings from state-year-industry fixed effects models support the earnings and employment share effect hypotheses. A counterfactual simulation demonstrates that had union coverage in the U.S. remained stable from 1983 to 2017, the earnings returns to an occupation's RTI might not have declined between 1983 and 2017, rather than experiencing a 0.30 log point decline. Moreover, the observed pattern of occupational wage polarization in the U.S. during the 1990s might not have occurred. However, the higher relative earnings growth for high RTI occupations appears to come at the cost of accelerated declines in employment shares. Had union coverage remained constant, the mean RTI of occupations might have fallen by an additional 21 percent relative to the observed decline from 1983-2017. The findings suggest that theories connecting automation to occupational earnings trends must be rooted in politicalinstitutional context. Organized labor appears to shape the social consequences of technological change. 


\section{BACKGROUND \& THEORY}

\section{Automation \& Occupational Earnings}

Technological change has been central to analyses of the earnings distribution throughout recent decades. In the 1990s, labor market scholars advanced the concept of skill-biased technological change (SBTC), the idea that technological advancements strengthen the wage premium for workers with a college degree despite the rising supply of such workers (Katz and Murphy 1992). As aptly summarized in the title of Goldin's and Katz's (2008) book, “The Race Between Technology and Education," the SBTC framework views rising inequality through the lens of technology-propelled demand for more educated workers. As several sociologists have documented, the SBTC framework overlooks the importance of worker power in its diagnosis of rising inequality (e.g. Fernandez (2001), Kristal (2013)), but the framework also suffers from another flaw: it cannot explain why low-pay, service-sector occupations were experiencing rising earnings and employment shares relative to middle-pay occupations throughout the 1990s. These patterns of employment and wage polarization led a separate group of scholars to abandon the "skills" framework and instead adopt a "tasks-based" framework, focusing on the routineness of tasks performed by a given occupation (Acemoglu and Autor 2011, Autor and Dorn 2013a, Goos, Manning and Salomons 2009). In contrast to SBTC, routine-biased technological change (RBTC) could explain "the heterogeneous behavior of the top, middle and bottom of the earnings distribution" (Mishel, Schmitt and Shierholz 2013).

Specifically, the RBTC framework suggests that technological progress generates two primary consequences with respect to employment and earnings patterns (Acemoglu and Autor 2011, Autor, Levy and Murnane 2003, Goos, Manning and Salomons 2014). One is the polarization of employment structures: high RTI occupations, the most susceptible to automation, tend to be in the middle of the earnings and skill distributions (Acemoglu and Autor 2011, Dwyer 2013). Their decline thus leads to a dip in employment shares near the median of 
the earnings distribution. Meanwhile, technological advancements are theorized to take a factor-augmenting form for higher-skill occupations, contributing to rising employment shares at the top the earnings and skills distributions (Autor, Levy and Murnane 2003, Autor and Dorn 2013a). ${ }^{1}$ Though the decline in employment shares of high RTI occupations has been written about extensively in the context of the U.S., evidence suggests that the trend is also pervasive throughout other advanced economies (Goos, Manning and Salomons 2009, OECD 2017).

A second potential consequence of RBTC is that earnings of high RTI occupations may experience less favorable growth relative to low RTI occupations (Acemoglu and Autor 2011, Goos, Manning and Salomons 2009). If declining demand for routine tasks translates into declining relative earnings among high RTI occupations, then earnings polarization, in addition to employment polarization, might occur (Böhm 2017, Firpo, Fortin and Lemieux 2011). In the U.S. during the 1990s, for example, the earnings of occupations at the bottom and top of the wage distribution increased at a greater rate than earnings of occupations in the middle of the distribution (Acemoglu and Autor 2011). However, evidence from other advanced economies (and other decades within the U.S.) suggests that earnings polarization is far from the norm. In Germany, for example, occupational polarization has occurred without earnings polarization (Antonczyk, DeLeire and Fitzenberger 2010). Looking more broadly at a number of EU Member States, Naticchioni, Ragusa and Massari (2014) also find that technological change has not led to the polarization of earnings. In other words, job polarization appears to be pervasive across advanced economies, but earnings polarization has often not followed.

The inconsistency in the relative earnings growth of automatable occupations poses prima facie evidence against an important feature of the RBTC hypothesis. As Acemoglu and Autor (2011) describe, a central innovation of their "tasks framework" is its ability to simultaneously explain the decline of earnings in high RTI occupations and the rise of earnings in low-pay and high-pay occupations (wage polarization) (Mishel, Schmitt and Shierholz 2013). 
That earnings trends across many advanced economies do not align with this pattern raises an important question: under which conditions do the earnings of high RTI occupations continue to grow at a faster rate than less routine occupations?

One shortcoming of the RBTC hypothesis, as well as other estimations of the social consequences of automation, is a failure to appropriately account for the role of labor market institutions, and the strength of organized labor in particular, in shaping the effects of automation on occupational earnings trends. Put differently, this paper argues that the dominant practice of rooting theories of occupational earnings growth solely in structural terms overlooks the moderating role of organized labor.

\section{Labor Market Institutions \& Occupational Earnings Trends}

Labor market institutions have not been at the forefront of the RBTC literature. This is perhaps due to an extensive focus on a single country (the U.S.), or perhaps due to a greater focus on the employment effects of technological change. Regardless of cause, the relegation of institutions, and the role of organized labor in particular, is surprising given the rich history of literature on their role in shaping the earnings distribution within and between occupations (Biegert 2017, Brady 2009, Katz and Autor 1999, OECD 2011, VanHeuvelen 2018, Western and Rosenfeld 2011).

How might organized labor affect the social consequences of technological change? Building on prior sociological research relating to power resources theory and comparative institutions, I hypothesize that higher union membership within a state-industry inhibits declining earnings returns to an occupation's RTI. I refer to this as an earnings effect. Building on literature related to potential employment share effects of unionization, I then propose that organized labor can achieve higher earnings gains for high RTI occupations, but at the cost of an accelerated decline in employment shares. I describe the evidence supporting these two 
hypotheses in turn.

With respect to the earnings growth of high RTI occupations, it is first worth reiterating the baseline perspective in the RBTC literature. In a perfectly competitive market, economic theory suggests that the declining demand for routine tasks will generally translate into lower earnings for occupations at greater risk of automation, lest the individuals in the occupations lose their jobs altogether (Acemoglu and Autor 2011). However, the comparative literature on labor market institutions suggests that several contextual factors might impede a straightforward relationship between declining demand and declining earnings. Labor unions and collective bargaining, in particular, play a critical role in shaping the distribution of market earnings. From a cross-national perspective, high levels of bargaining coverage have been linked to more compressed earnings distributions (Hirsch 2004, OECD 2017, Visser and Checchi 2011). From a cross-state perspective within the U.S., higher levels of unionization have been linked to lower levels of in-work poverty (Brady, Baker and Finnigan 2013) and more egalitarians pay norms (VanHeuvelen 2018, Western and Rosenfeld 2011).

Power resources theory, central to the comparative institutions literature, also points to the role organized labor as central actor in a broader, class-based struggle over the distribution of resources (Brady 2009, Brady, Blome and Kleider 2016, Jacobs and Dirlam 2016, Korpi 1983, Korpi 1985, Wilmers 2017). Most directly, unions and collective bargaining agreements generally contribute to higher earnings for covered workers, as well as improvements in working conditions (Brady, Blome and Kleider 2016, Kalleberg, Wallace and Raffalovich 1984, Kristal 2013). Unions have lifted earnings across a broad range of occupation types, but the earnings effects have historically been stronger among workers in industrial occupations (DiNardo, Fortin and Lemieux 1996). Such occupations tend to be in the middle of the earnings distribution and tend to have a higher RTI; as such, they have been the particular focus of the earnings polarization literature (Autor and Dorn 2013a). In addition to contributing to earnings 
increases for unionized workers, unions also have spillover effects for non-unionized workers (Denice and Rosenfeld 2018). Thus, the effects of unionization on a worker's earnings growth cannot be understood solely as a function of the individual's union status, but should also take into account the union membership of other workers in the person's firm or industry.

The bargaining power that a trade union provides is likely to be particularly important when a given industry or occupation is under threat. Where organized labor is weakest, market forces are more likely to exert downward pressure on the earnings of high RTI occupations (Nickell and Andrews 1983). Where organized labor has greater bargaining power, such occupations are perhaps likely to experience more favorable earnings growth. This possible earnings effect suggests that higher union membership within a state-industry inhibits declining earnings returns to an occupation's RTI. Put differently, declining union membership contributes to declining relative earnings growth for occupations at greater risk of automation.

Might the enhanced earnings growth for union members, however, come at a cost? This study's second hypothesis posits that higher union membership within a state-industry is also associated with accelerated declines in the employment shares of high routine occupations. Put differently, this potential employment share effect suggests that the average RTI of occupations within a state-industry declines at a faster rate when union membership is higher. This hypothesis is rooted in related bodies of research that have worked to understand the potential employment effects of unionization (Leonard 1992, Lindbeck and Snower 2001, Nickell and Andrews 1983, Pencavel 1984) and the role of labor costs in shaping the decline of routine occupations (Lordan and Neumark 2017).

At the core of a potential employment share effect is evidence that in a context of declining demand for routine tasks, the rate at which routine occupations experience declining employment shares is conditional on their relative labor costs. As one example, Lordan and Neumark (2017) find that higher labor costs due to minimum wage increases reduce the share 
of high routine jobs in a given state and industry. Moreover, rising labor costs contributed to "increases in the likelihood that low-skilled workers in automatable jobs become nonemployed or employed in worse jobs." Consider also the relative growth of high routine jobs in states with lower labor costs and anti-union Right to Work laws in recent decades (Newman 1983). Foreign auto manufacturers, such as Hyundai, Nissan, and Toyota, have opened U.S. plants and created routine jobs almost exclusively in states across the American South - a region where wages are lower and where organized labor has struggled to maintain a presence (Rosenfeld 2014). ${ }^{2}$ Internationally, the tension among declining demand, earnings, and employment was also present in German manufacturing industries during the recent financial crisis. Recognizing that declining consumption might otherwise force large layoffs, many German workers participated in the "short-time work" program, reducing their hours (with subsidies from the state) to reduce their firm's aggregate labor costs. Without the temporary reduction in labor costs, "unemployment would have risen by approximately twice as much as it actually did" (Brenke, Rinne and Zimmermann 2011).

Given this evidence of trade-offs between employment and earnings for routine occupations, and the fact that routine occupations already face a rising employment penalty (Goos, Manning and Salomons 2009), I expect that higher shares of union membership, insofar as they are successful in protecting the relative earnings of routine occupations, will amplify the rising employment penalty for such occupations. Importantly, this does not necessarily imply that unionized, routine workers bear the costs of the accelerated decline in routine employment shares. Instead, declines in the hiring of routine occupations (relative to lower RTI occupations) could plausibly drive the aggregate decline in the average RTI of occupations within an industry. This pattern would be consistent with results from Cortes (2016) who, in a panel study of the employment trajectories of routine workers, finds that the decline of routine jobs in the U.S. labor market is largely due to reduced hiring of routine workers rather than 
accelerations in layoffs. Similarly, research from Fernandez (2001), Kimeldorf (1992), and Ahlquist and Levi (2013) find that unions negotiate the introduction of labor-replacing technologies in a way that dampens their own employment losses. Thus, higher union membership might enhance the employment protections for unionized members, but contribute to (1) declines in hiring of high RTI occupations within the state-industry relative to the pace of hiring in state-industries with lower labor costs (consistent with Lordan and Neumark (2017)) and (2) declines in the hiring of high RTI occupations within the state-industry relative to the pace of hiring for low RTI occupations

(consistent with Cortes (2016)). The net effect of either of these outcomes is a faster decline in the average RTI of occupations where union membership is more resilient.

The earnings and employment effects may be interconnected. With fewer job opportunities available, a jobseeker who would otherwise pursue a high RTI occupation may decide to pursue a lower pay occupation instead, further decreasing the share of high RTI occupations relative to the full distribution of jobs. Increased competition for these lower-pay jobs might inhibit earnings growth for such occupations and help to ensure that the relative earnings of routine jobs continue to grow at a faster pace. Thus, an employment share effect might reinforce the hypothesized earnings effect. Indeed, Autor and Dorn (2013) speculate that the decline of wages in low-pay, low-RTI occupations in the U.S. in recent years is partly due to more 'middle-skill' workers competing for the low pay occupations.

\section{Potential Objections}

There are at least three explanations for why empirical evidence may not support this study's hypotheses. First, variation in trends of state-industry union membership may be too small to reveal meaningful effects on the relative earnings trends. Consider that levels of unionization have declined across all states in the U.S. in recent decades (Hirsch and MacPherson 2003). However, descriptive statistics from the Current Population Survey 
(discussed in more detail in the next section) suggest large variation in rates of union decline across the 50 states. In Vermont, for example, union membership declined from 17.5 percent in 1983 to 15.3 percent in 2015, a 13 percent decline. In Utah, by contrast, union membership fell from 23.1 percent to 6.3 percent, a 73 percent decline, over the same timeframe. The average, unweighted decline across the 50 states was 44 percent with a standard deviation of 12.3 percent.

Second, there may be some relationship between technological change and declines in union membership, which could affect this study's focus on the relationship between union membership and the earnings returns to an occupation's RTI. Later, I detail how I account for this possibility in my estimation strategy. However, it is worth noting that prior research suggests that political and institutional forces can be as important as structural forces in explaining the decline of unionization. Anti-union laws, such as Right to Work (RTW) legislation, and regulations restricting union formation are key contributors of organized labor's ongoing decline and perhaps explain more of the decline in union membership than any recent acceleration in labor-replacing technologies (Hertel-Fernandez 2019, Thelen 2015). Descriptive evidence from the CPS again supports these claims. In RTW states, union membership is lower and has declined at a faster rate from 1983 to 2017 relative to non-RTW states. Nonetheless, I detail below several empirical steps to ensure that this study can appropriately assess the effects of union membership on the earnings returns to RTI, independent of the relationship between union membership and technological change.

Third, and relatedly, this study does not measure whether union membership attracts or repels technological innovation. This is a potential limitation of this study and a relationship that should continue to be investigated in future work. ${ }^{3}$ On one hand, unionized routine workers could attract greater technological adoption (Acemoglu 2002). In an optimistic take on this scenario, the routine workers use the technological innovations to enhance their productivity 
and, in turn, their earnings. That routine workers, rather than higher-pay and "higher-skill" workers, would primarily benefit from the onset of new technology, however, would be inconsistent with both the SBTC and RBTC literatures (Autor and Dorn 2013b, Goldin and Katz 2008). More in line with prior evidence is the more pessimistic scenario: unionized routine workers allow technological innovation, and perhaps even attract it due to their higher relative labor costs, but negotiate the implementation of the new technologies in a way that protects their relative earnings and employment (e.g. Fernandez 2001). Finally, an alternative argument, based on the capital hold-up literature, suggests that firms are less likely to invest in new technology when labor is stronger, as the returns to their investments would be shared among employees in the form of higher wages (Card, Devicienti and Maida 2014, Cardullo, Conti and Sulis 2015). Ultimately, this study does explicitly test which of these pathways is more plausible and therefore refrains from ascertaining on which is more likely. Instead, this analysis narrows in on the role of worker power in shaping the relative earnings trends of routine occupations, regardless of whether unions attract or repel technological innovation in the first place. Results should be interpreted with this limitation in mind.

\section{DATA \& METHODS}

I test the earnings and employment effect hypotheses on a sample of 3.3 million employed adults (ages 18-65) in the U.S. using the Current Population Survey Merged Outgoing Rotation Group (CPS MORG) from 1983 to 2017. The CPS MORG provides detailed data on the weekly earnings of employed adults, as well as data on each worker's union membership.

I measure occupational earnings as the log of weekly earnings of employed adults. Weekly earnings are adjusted for inflation using the CPI and set to 2014 USD. Self-employed and part-time workers (those working fewer than 30 hours per week) are excluded from the analysis. I exclude workers reporting less than $\$ 1$ per hour in earnings. I multiply the earnings 
of top-coded earners by 1.4 in the primary analysis, following recommendations in Denice and Rosenfeld (2018) and Lemieux (2006). Results without the top-code adjustments produce similar findings. Following standard practice when using union data in the MORG samples, I exclude allocated earners from the data, as the CPS does not include union status in its allocation model (Brueckner and Neumark 2014, Denice and Rosenfeld 2018). Following Rosenfeld (2014) and Denice and Rosenfeld (2018), I exclude data from 1994 and 1995 due to a lack of valid allocation flags during those years. I use recommendations from Hirsch and Schumacher (2004) to identify allocated earners in other years. Descriptive statistics are presented in Appendix B.

In the primary earnings analyses, I measure union status first at the individual level and, second, at the state-industry level using three-year rolling averages of union coverage within each industry in each state. In a sensitivity check, I also produce estimates using stateindustry union data only among high RTI occupations, or those in the top one-third of the RTI distribution. Doing so helps to sidestep a potential mechanical relationship between technological change and union membership. In the first approach, levels of union coverage within a state-industry may decline as employment shares of machine operators decline if union coverage is particularly concentrated among machine operators (as one example). In the sensitivity check, I measure the coverage among machine operators; thus, even as employment shares of operators decline, the share of the remaining workers who are covered need not experience a mechanical decline. The results of the sensitivity check, presented in the Supplemental Appendix (Table S1), align closely with the results from the primary analysis.

I follow Autor and Dorn (2013a) in measuring the routine task intensity (RTI) of all occupations within the dataset. The RTI index has become the standard practice for measuring the task content of occupations (Goos, Manning and Salomons 2014:2511). Routine tasks consist of repeated sequence of actions and are more easily replaceable through technological 
innovations. A higher RTI score thus indicates that an occupation is more 'routine-task intensive' and, thus, can more readily be automated. In Appendix A, I provide more information on the construction of the RTI index.

I use the time-consistent occupation codes from Autor and Dorn (2013) to merge in the RTI data. The crosswalks that Autor and Dorn apply are meant to allow for an examination of near-identical occupations over time (despite changes to occupational coding schemes within the CPS), but they remain imperfect. Similar to Mishel, Schmitt and Shierholz (2013), I find that inconsistencies in the descriptive data appear in 2003, the year in which the revised occupation codes were introduced. From 1983 to 2002, the mean RTI of occupations falls from 1.27 to 0.96 . In 2003, however, the mean RTI of occupations increases from 0.96 to 1.04 before continuing its steady decline. As discussed in the Estimation Strategy and Sensitivity Checks below, I take several steps to account for the inconsistencies in the data due to the 2003 change in occupation codes.

\section{Estimation Strategy}

I first test whether higher union coverage within a state-industry in the U.S. does, indeed, contribute to higher earnings returns to an occupation's RTI. This would be consistent with the earnings effect hypothesis. To test this, I begin with a simple estimation of trends in the returns to an occupation's RTI while controlling for individual characteristics that likely affect labor supply. This estimation is modeled as follows:

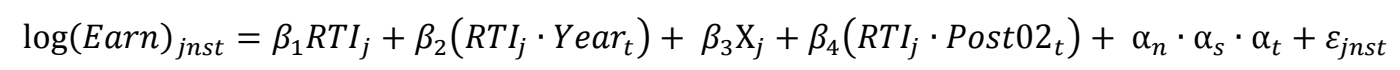

The outcome variable is the log weekly earnings of an individual $(j)$ working in industry $(n)$ in a state $(s)$ and year $(t) . R T I$ represents the routine task intensity of the occupation, scaled from zero (least routine) to 1 (most routine). The ear $_{t}$ variable included in the interaction term 
(see $\beta_{2}$ ) represents a linear time trend, following similar specifications from and Goos, Manning and Salomons (2014) and Mahutga, Curran and Roberts (2018). Thus, if $\beta_{2}$ is positive and statistically significant, this would imply that the earnings returns to higher RTI are increasing over time, independent of composition effects, such as a rise in educational attainment. Vector $X$ controls for demographic features (age, the square of age, education level, sex, marital status, a binary indicator of whether the worker lives in the city center, and race/ethnicity in the form of binary indicators for Black, Hispanic/Latino, or Other Non-White). The inclusion of these controls is standard in earnings estimates and is meant to account for other factors beyond unionization that might affect individual earnings. To account for the bias in levels of RTI introduced during the 2003 occupation code changes, I include an interaction for RTI and a dummy variable $\left(\operatorname{Post~} 02_{t}\right)$ indicating whether the given year comes before or after the 2003 coding change. In the Supplemental Appendix (Table S2), I also replicate all analyses segmenting the data into two sets of years: 1983 to 2002 and 2003 to 2017 . The results are consistent with the primary analyses. Finally, the model also includes state-industry-year fixed effects. In practice, this takes into account that earnings trends are likely to vary across state and industry. The main effect of any state-level variables (such as union coverage, but including other factors, such as minimum wages changes) is accounted for in the state-year effects. I apply robust standard errors clustered at the state level. ${ }^{4}$

I then extend Equation (1) to measure the moderating role of union coverage on the trends in earnings returns to an RTI's occupation. I first operationalize union coverage at the individual level using worker-level data on union membership. Given evidence that higher union membership also boosts the earnings of non-union members (Denice and Rosenfeld 2018), I then operationalize union coverage as the mean of state-industry-year union membership, as discussed earlier. 
Adding in union coverage creates a three-way interaction between RTI, the linear year trend, and union coverage:

$$
\begin{aligned}
& \log (\text { Earn })_{j n s t}=\beta_{1} R T I_{j}+\beta_{2}\left(R T I_{j} \cdot \text { Year }_{t}\right)+\beta_{3}\left(R T I_{j} \cdot \text { Year }_{t} \cdot \text { Union }_{s t}\right)+\cdots+\beta_{4} \mathrm{X}_{j}+ \\
& \beta_{5}\left(R_{T I} \cdot \operatorname{Post}_{j} 2_{t}\right)+\alpha_{n} \cdot \alpha_{s} \cdot \alpha_{t}+\varepsilon_{j n s t}
\end{aligned}
$$

Note that the three-way interaction in Equation (2) also creates interactions between union and year, as well as RTI and union; I conceal these from the formal estimation above solely for brevity. The primary coefficient of interest becomes $\beta_{3}$. A positive and significant slope would suggest that union coverage is associated with more favorable earnings returns to an occupation's RTI over time. Put differently, such a finding would support the hypothesis that higher union coverage propels the relative earnings growth of jobs at greater risk of automation. This finding would corroborate the study's primary hypothesis.

I then turn toward testing for a possible employment effect. To test whether higher union coverage leads to accelerated declines in occupations at greater risk of automation, I estimate the following:

$$
\text { RTI }_{\text {jnst }}=\beta_{1}\left(\text { Union }_{\text {st }} \cdot \text { Year }_{t}\right)+\beta_{2} \mathrm{X}_{j}+\beta_{3} \text { Post } 02+\alpha_{n} \cdot \alpha_{s}+\alpha_{s} \cdot \alpha_{t}+\varepsilon_{j n s t}
$$

$R T I_{j n s t}$ is again an occupation's routine task intensity. Year $_{t}$ represents the linear time trend. Vector $X$ controls for the same demographic features as before. Union membership is measured again at the state-industry-year level. If $\beta_{1}$ is negative and significant, this would suggest that rising union coverage within a state-industry hastens the decline in the employment shares of occupations at greater risk of automation, independent of compositional changes. Put differently, such a finding would suggest that more resilient union membership contributes to an accelerated decline in the share of occupations with higher RTI. 


\section{FINDINGS}

I first present descriptive findings on trends in the returns to RTI across state-industries with below-average and above-average union coverage. Though my hypotheses and estimation strategy focus on the effect of within-state and within-industry variation in levels of union coverage on the returns to an occupation's RTI, it is instructive to first examine this relationship across states to see if the anticipated patterns exist.

Figure 1: Earnings returns to routine task intensity (RTI) by union membership of stateindustry

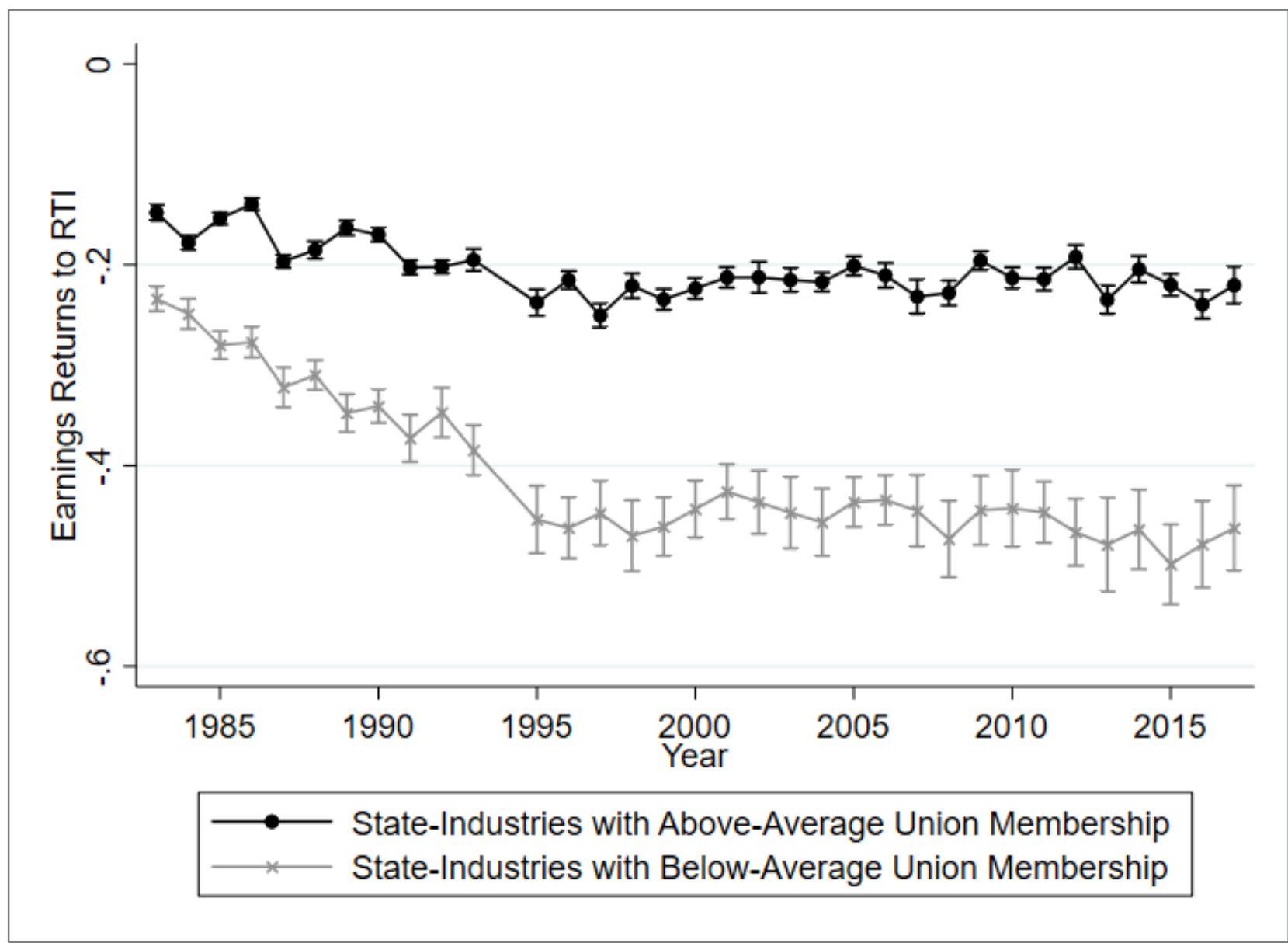

Note: Figure displays the marginal effects of an occupation's RTI on log weekly earnings.

Figure 1 presents the earnings returns to RTI from 1983 to 2017 depending on the stateindustry's union membership. State-industries with above-average union membership in the given year are presented in the black line, while those with below-average union membership 
are presented in the lighter-colored line. Two main patterns stand out from the figure. First, the earnings returns to an occupation's RTI are consistently lower in states with below-average union membership. Put differently, an occupation at greater risk of automation is likely to receive lower relative earnings if working in a state with lower levels of unionization. In 2017, the high- and low-union states differed in returns to RTI by a factor of two (an average return of -0.21 versus $-0.45 \log$ points, respectively, for each percentage point increase in an occupation's RTI).

Second, the trends differ between the two groups. In state-industries with above-average union membership, the earnings returns to RTI decline from -0.15 to $-0.22 \log$ points $(-0.07 \log$ point change) from 1983 to 2017. In state-industries with below-average union membership, the decline is much steeper. From 1983 to 2017 , the earnings returns to RTI fall from -0.23 to $-0.46 \log$ points, a $-0.23 \log$ point change. Whether examining levels or trends, the descriptive evidence suggests that occupations at greater risk of automation experience higher relative earnings in a state-industry with above-average levels of unionization.

Do these relationships tend to hold when we look within each state-industry over time? To further investigate the role of unionization on the earnings returns to an occupation's RTI, I now turn toward the formal estimates of the hypotheses.

Table 1 presents the results of Equations (1) and (2). Model 1 looks at whether the earnings returns to an occupation's RTI has declined, on average, from 1983 to 2017. The interaction term of RTI and the linear time-trend ("year") is negative and statistically significant, indicating that the returns to RTI have, on average, fallen with each year. Put differently, high RTI occupations tend to see less favorable earnings growth relative to lower RTI occupations, all else equal. 
Table 1: Estimations of Earnings Trends of Occupations by Routine Task Intensity (RTI) and Level of Union Coverage (1983-2017)

\begin{tabular}{|c|c|c|c|c|}
\hline & (1) Trends & $\begin{array}{l}\text { (2) Individual } \\
\text { Union }\end{array}$ & $\begin{array}{c}\text { (3) State- } \\
\text { Industry Union }\end{array}$ & $\begin{array}{l}\text { (4) State- } \\
\text { Industry Union } \\
\text { on Non-Union }\end{array}$ \\
\hline RTI & $\begin{array}{c}-.217 * * * \\
(.001)\end{array}$ & $\begin{array}{c}-.221 * * * \\
(.010)\end{array}$ & $\begin{array}{c}-.249 * * * \\
(.016)\end{array}$ & $\begin{array}{c}-.249 * * * \\
(.017)\end{array}$ \\
\hline Union & & $\begin{array}{c}.115^{* * *} \\
(.001)\end{array}$ & & \\
\hline $\begin{array}{l}\text { RTI } \\
\text { \# Year (Linear) }\end{array}$ & $\begin{array}{c}-.006 * * * \\
(.001)\end{array}$ & $\begin{array}{c}-.006 * * * \\
(.001)\end{array}$ & $\begin{array}{c}-.004 * * * \\
(.001)\end{array}$ & $\begin{array}{c}-.002 * * \\
(.001)\end{array}$ \\
\hline $\begin{array}{l}\text { RTI } \\
\text { \# Union }\end{array}$ & & $\begin{array}{c}.098 * * * \\
(.021)\end{array}$ & $\begin{array}{c}.048 * * * \\
(.012)\end{array}$ & $\begin{array}{l}.056^{* *} \\
(.018)\end{array}$ \\
\hline $\begin{array}{l}\text { Union } \\
\text { \# Year (Linear) }\end{array}$ & & $\begin{array}{c}-.003 * * * \\
(.000)\end{array}$ & & \\
\hline $\begin{array}{l}\text { RTI } \\
\text { \# Union } \\
\text { \# Year (Linear) }\end{array}$ & & $\begin{array}{c}.003 * * * \\
(.001)\end{array}$ & $\begin{array}{c}.005^{* * * *} \\
(.000)\end{array}$ & $\begin{array}{l}.006^{* * *} \\
(.000)\end{array}$ \\
\hline Observations & $3,246,862$ & $3,246,862$ & $3,246,862$ & $2,649,962$ \\
\hline
\end{tabular}

All models include individual-level controls (age, age squared, race/ethnicity, education, sex, marital status, and urban/non-urban dummy), state-industry-year fixed effects, and an interaction of RTI and a pre/post-2003 dummy. Main effects of linear time trend and state-industry union membership omitted due to use of state-year-industry fixed effects. Robust standard errors in parentheses. Standardized coefficients presented for union coverage. ${ }^{*} p<$ $0.05,{ }^{* *} p<0.01,{ }^{* * *} p<0.001$. 
To what extent can within-industry variation in union coverage help to explain differences in the earnings returns to an occupation's RTI over time? Model 2 presents the results of the three-way interactions using individual-level union membership. The positive and significant slope for the RTI, year, and union coverage interaction suggests that union membership is associated with greater relative earnings growth for occupations with higher RTI. In other words, declining union membership is associated with declining earnings returns to an occupation's RTI.

Model 3 presents the results while operationalizing union membership at the stateindustry level for each year. Given evidence of union spillover effects to non-union workers, As hypothesized, higher union coverage within a state-industry is associated with even greater relative earnings growth for occupations with higher RTI. Declining levels of union coverage within a state-industry are associated with declining earnings returns to an occupation's RTI. Specifically, a one standard deviation increase in levels of union coverage is associated with a 0.5 percent increase, on average, in the earnings returns to an occupation's RTI. ${ }^{5}$

Model 4 shows why measuring state-industry union membership, rather than individual union membership, is particularly useful. The results here repeat the same estimate as Model 3, but only including non-union workers. Consistent with results from Denice and Rosenfeld (2018), the findings suggest that higher union membership at the state-industry level is beneficial for the earnings returns to an occupation's RTI even among the non-unionized.

To visually depict the magnitude of the results in Table 1, Figure 2 shows the marginal effects of RTI on weekly earnings by year and union coverage. The marginal effects are estimated using the results from Model 3 in Table 1. Each year is labeled on the X-axis, while the Y-axis depicts the marginal effect of RTI on log weekly earnings. The three lines show how the marginal effects vary by level of union membership within the state-industry. The top line shows that the marginal effect of RTI on earnings actually increases over time when union 
membership is two standard deviations (SD) above the mean. In 2017, in fact, occupations at greater risk of automation are estimated to face no earnings penalty relative to lower RTI occupations, on average, if union coverage were at two SD above the mean or higher.

Figure 2: Marginal effects of routine task intensity (RTI) on log weekly earnings by year and state-industry union membership

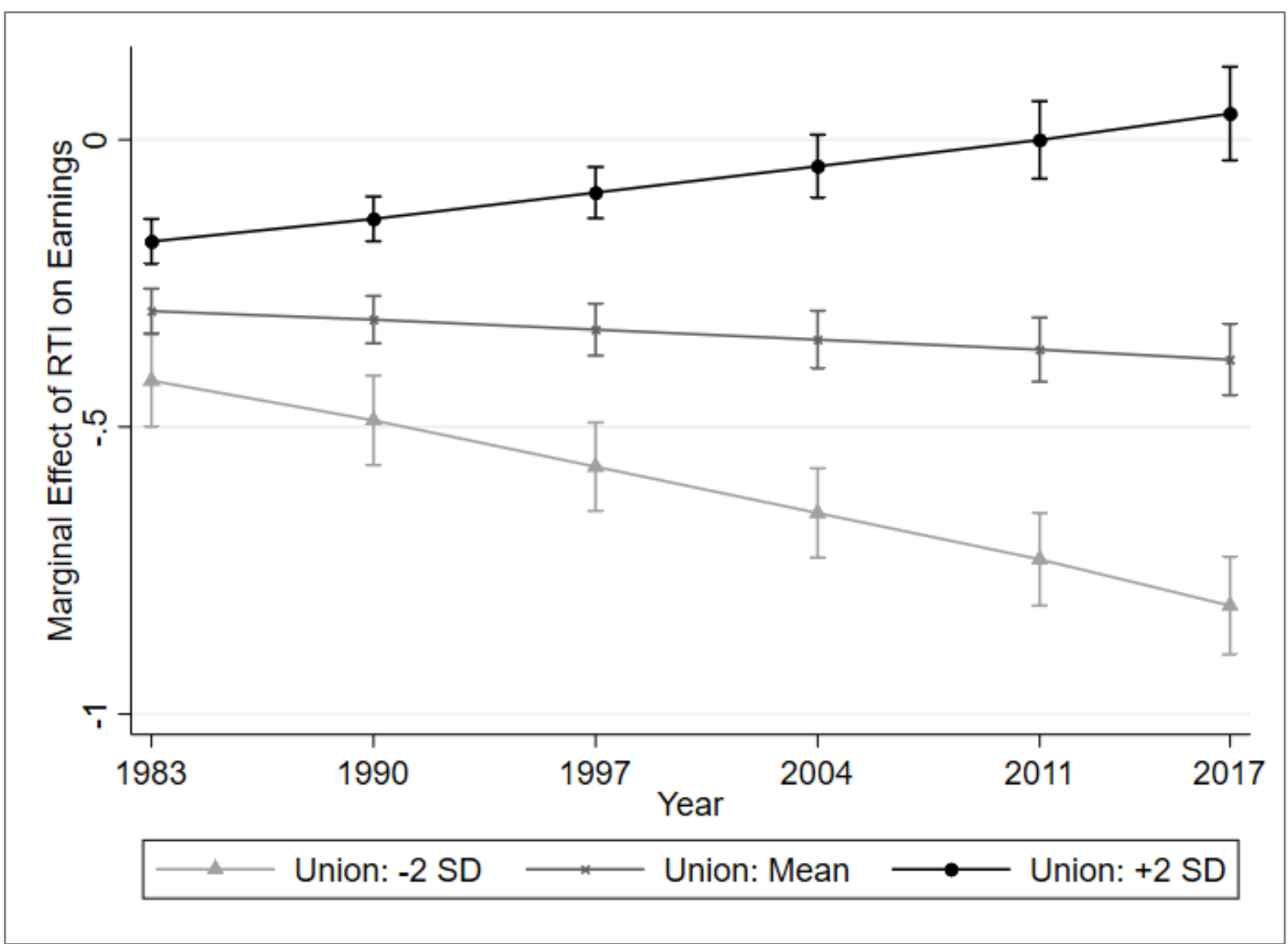

Note: Marginal effects from Model 3 of Table 1.

In contrast, occupations at risk of automation fare much worse when state-industry union membership is low. At two SD below the mean, the penalty associated with an occupation's RTI worsens over time. Moreover, the difference in returns to RTI for occupations in high-union versus low-union state-industries widens with each year. If a state-industry's union density falls from two SD above the mean to the mean, we can expect a $0.5 \log$ point decline, on average, in earnings returns to an occupation's RTI in 2017. Falling from the mean 
to two SD below the mean results in additional $0.5 \log$ point decline. These results support this study's primary hypothesis that higher union coverage within a state-industry is beneficial for the relative earnings trends of higher RTI occupations.

Figure 3: Counterfactual returns to an occupation's RTI had union coverage in the U.S. remained constant from 1983 to 2017

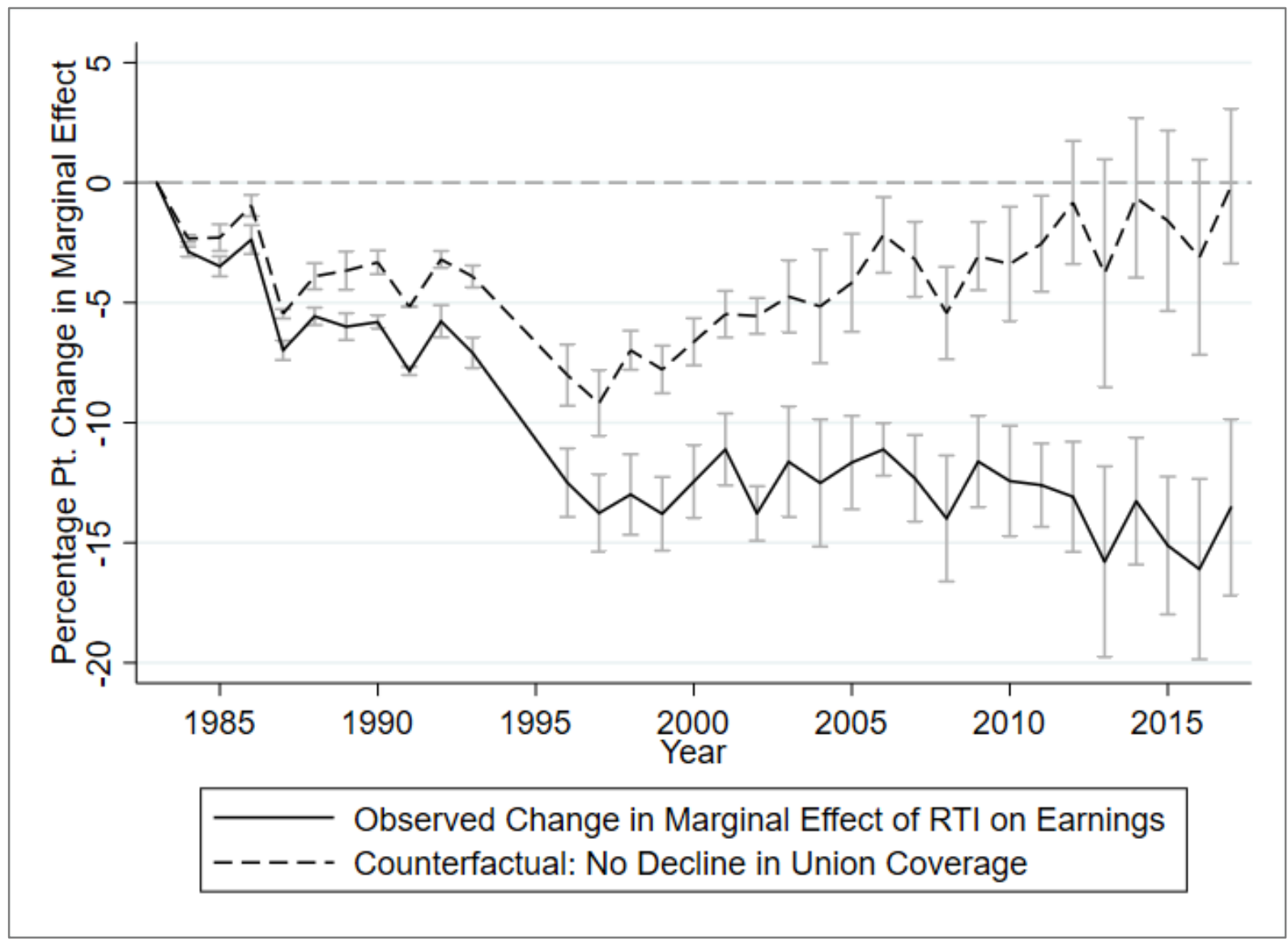

Note: Marginal effects of RTI on log earnings. Findings from Table 1, Model 3.

To further contextualize the results, Figure 3 presents a counterfactual evolution of the earnings returns to an occupation's RTI if the U.S. had experienced no decline in union coverage among high RTI occupations from 1983 to 2017. In this scenario, union coverage would have remained steady at an average of 26.2 percent rather than dropping to an average of 13.7 percent by 2017. These counterfactual estimates are produced using the findings from Model 3 in Table 1, but with year dummies rather than linear time trends in the interaction to 
account for any non-linear, year-to-year differences in relative earnings growth rates. The solid black line in Figure 3 represents the observed trend in the marginal effects of RTI on earnings. The observed trend shows a decline in returns to RTI from 1983 to 2017. Consistent with prior evidence of occupational earnings polarization, the observed trend shows a steep decline from 1990 to 2000, but no statistically significant difference from 2000 to 2017 .

The dashed line represents the counterfactual earnings trends if levels of union coverage had not declined from 1983 levels. As opposed to the 14-percentage point decline in the observed trend from 1983 to 2017, the counterfactual trend suggests that the earnings returns to an occupation's RTI might not have fallen between 1983 and 2017 had union coverage remained stable from 1983 onward. Moreover, the period of occupational earnings polarization in the 1990s might not have occurred in the counterfactual scenario. These counterfactuals are partial-equilibrium estimates and do not take into account other changes that might occur if union coverage remained constant. The findings should be interpreted accordingly. Nonetheless, they suggest that the earnings trends of occupations at greater risk of automation are conditional on the strength of organized labor.

In the Supplemental Appendix (Figure S1), I present a version of Figure 3 that visualizes the returns to an occupation's RTI over time conditional on individual-level union membership, rather than state-level union membership, using the results from Model 2 of Table 1. Compared to the 13.4 percentage point difference in the counterfactual and observed earnings trends when using state-industry union membership, the difference in the estimated earnings returns to RTI for union versus non-union members is 9 percentage points. In this alternative specification, the earnings returns to RTI for union members decline by 4.6 percentage points between 1983 and 2017, compared to 0.2 percentage points in the state-industry counterfactual. This trend is still more favorable than the 13.3 percentage point decline that non-union members experience. Thus, this study's primary hypothesis is supported whether investigating individual or state- 
industry union membership, but the effects are slightly stronger when analyzing state-industry union membership.

Figure 4: Estimated increase in earnings by occupation type in 2017 had union coverage in the U.S. not declined from 1983 levels

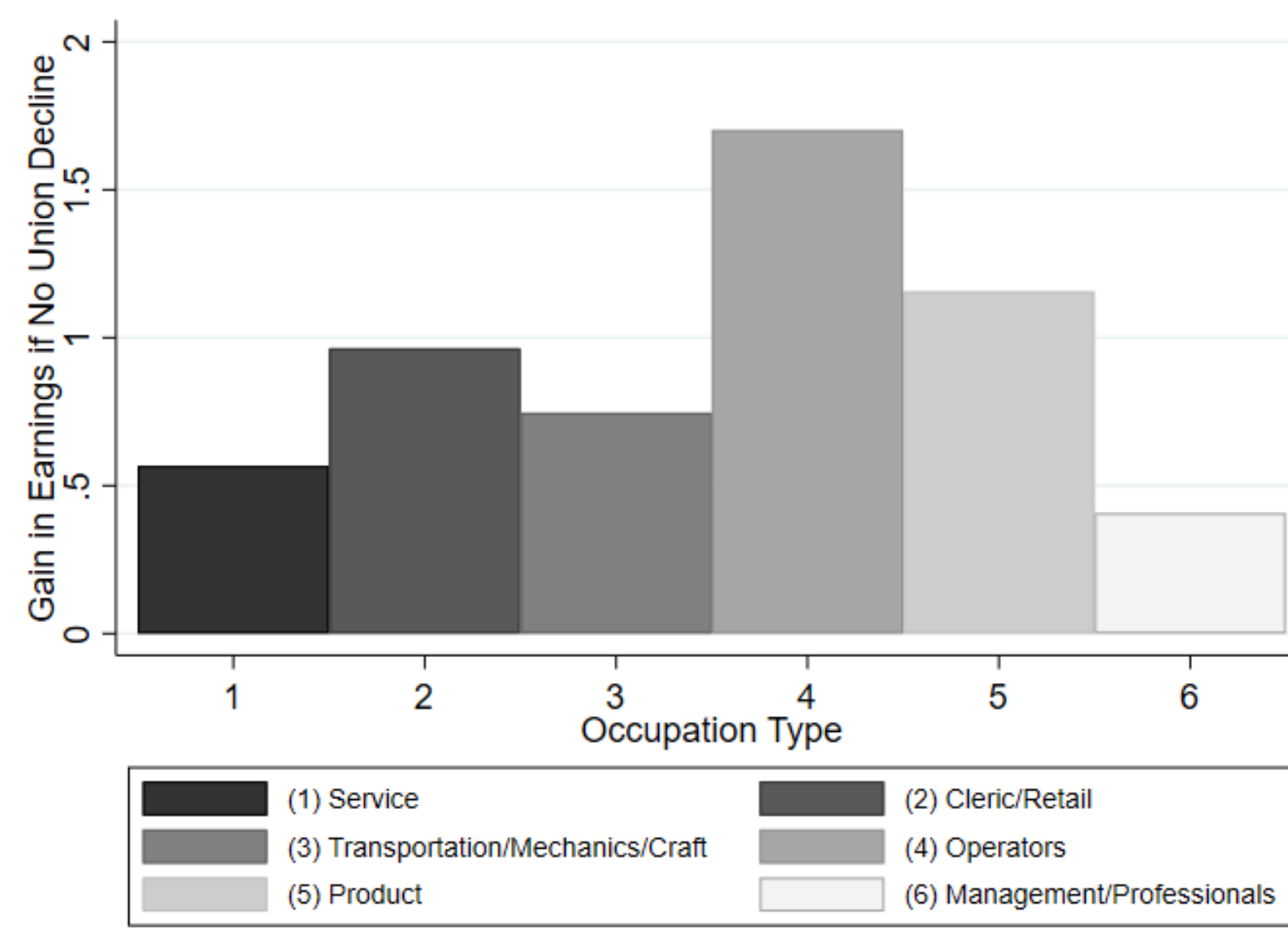

Note: Occupation groups sorted from lowest (left) to highest (right) mean in wage in 1983. Y-Axis: gain in log earnings if union membership remained constant from 1983 to 2017.

For further evidence of the relationship with earnings polarization, Figure 4 plots the potential earnings gains by occupation type in 2017 had union coverage remained steady from 1983 onward (using the same estimates from Table 1). The figure shows the estimated increase in earnings for the six primary occupation categories featured in Autor and Dorn (2013). The occupations are lined from the lowest average pay in 1983 (beginning with Service occupations on the left side) to the highest average pay (Management/Professionals on the right). The findings show that the greatest increase in earnings would occur among the Operators 
occupation group, which includes machine operators and similar high RTI occupations. In the absence of union decline from 1983 to 2017, the estimates suggest that the Operators group would see an increase in earnings of about $1.5 \mathrm{log}$ points, higher than the other occupation groups. Notably, the occupations benefiting the most are in the middle of the earnings distribution. Thus, an increase in their earnings acts as the inverse of earnings polarization. Again, the evidence suggests that assessments of the earnings growth of high RTI occupations, as well as theories regarding the sources of earnings polarization in the 1990s, must take into account the declining strength of organized labor. Had union coverage remained constant from 1983 onward, rather than declining by around 50 percent, occupations at greater risk of automation would likely fare much better in terms of their relative earnings growth.

\section{Evidence of an Employment Effect?}

The evidence presented thus far supports the hypothesis that stronger unions inhibit a decline in the earnings returns to an occupation's RTI. But, do the gains in relative earnings come at a cost? Specifically, do we find that stronger union coverage within a state-industry is associated with an accelerated decline in the share of occupations at risk of automation? Table 2 presents the results of Equation (3), which tests for a possible employment share effect. 
Table 2: OLS Estimates of Effect of State-Industry Union Coverage on Trends in Routine Task Intensity of Employed Adults

\begin{tabular}{lcc}
\hline $\begin{array}{l}\text { Outcome: RTI of employed } \\
\text { adults }\end{array}$ & $(1)$ & $(2)$ \\
\hline & & \\
Year (Linear) & $\left(.004^{* * *}\right.$ & $-.010^{* * *}$ \\
& & $(.001)$ \\
Union Coverage & $-.064 * * *$ \\
& $(.008)$ \\
Union Coverage & \\
\# Year (Linear) & & $-.001 * *$ \\
\multicolumn{1}{c}{ Observations } & $(.000)$ \\
\hline
\end{tabular}

Dependent variable: RTI. All models include individual-level controls (age, age squared, race/ethnicity, education, sex, marriage status, and urban/non-urban dummy), state-industry fixed effects, state-year fixed effects, and an interaction of RTI and a pre/post-2003 dummy. Robust standard errors in parentheses. Standardized coefficients presented for collective bargaining coverage. ${ }^{*} p<0.05,{ }^{* *} p<0.01,{ }^{* * *} p<0.001$.

Model 1 first looks at trends in the RTI of all occupations within state-industries. As expected, the linear time trend is negative and significant. This indicates that occupations at greater risk of automation are, indeed, losing employment shares over time relative to less routine occupations. Model 2 adds the interaction of union coverage and the linear time trend. If the interaction were to be negative and significant, this would suggest that the higher union coverage within a state-industry contributes to faster decline in employment shares of high RTI occupations within a state-industry. The evidence supports this conclusion. 
Figure 5: Counterfactual change in mean RTI of occupations had union coverage not declined from 1983 to 2017

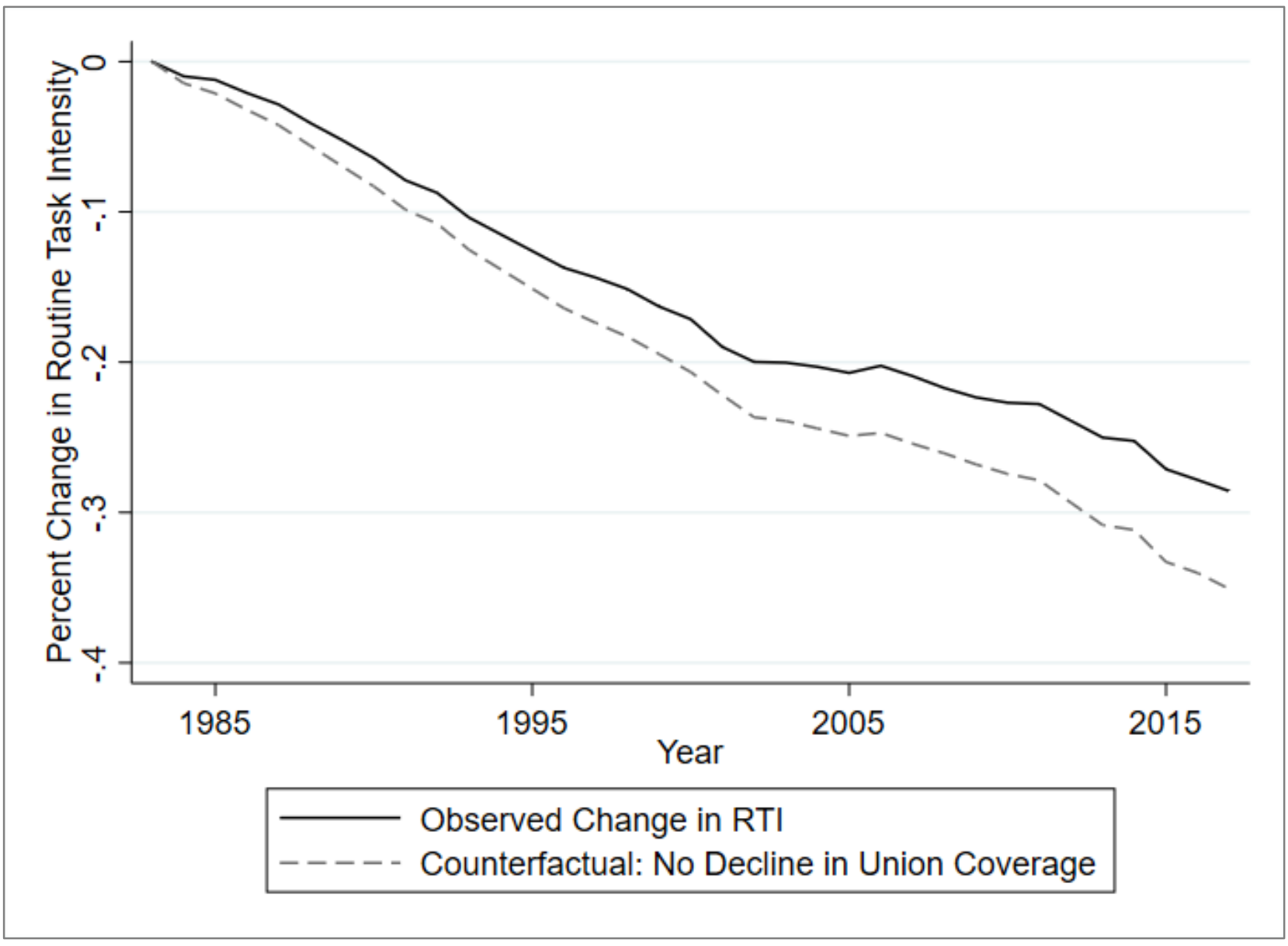

To contextualize this finding, Figure 5 displays the same counterfactual as applied in the earnings estimates. Had union coverage remained constant from 1983 to 2017, to what extent would the mean RTI of occupations have declined? The observed trend (solid line) shows that the mean RTI of occupations fell by around 28 percent from 1983 to 2017 . Had union coverage remained constant, it would have fallen by around 34 percent instead, according to the estimates. The difference is 6 percentage points, or around 21 percent steeper than the observed decline. The results support the existence of a negative employment share effect.

To summarize the results, when union coverage within a state-industry is higher, occupations at greater risk of automation experience greater earnings growth, but also tend to experience accelerated declines in employment shares. Returning to the language of the RBTC 
literature, we can thus conclude that organized labor inhibits the polarization of occupational earnings, but also appears to accelerate the polarization of occupational employment shares.

\section{Sensitivity Checks}

I present several sensitivity checks in the Supplemental Appendix to assess the consistency of the study's findings under alternative model specifications. First, I test whether the results hold when a state-industry's union membership among high RTI occupations is substituted for state-industry union membership among all occupations. Following Lordan and Neumark (2017), high RTI occupations are those defined in the top one-third of the RTI distribution. The advantage of such an approach is the side-stepping of a potential mechanical relationship between technological change and the decline of union membership. If union membership is concentrated among routine occupations, and automation affects routine occupations more than occupations, then automation may drive down levels of union membership. When measuring union membership among high RTI occupations, I am capturing the mean unionization among the high RTI occupations that remain, regardless of their overall employment shares. The results, as shown in Table S1, are consistent with the study's primary findings.

As an additional check, I re-estimate the primary models (operationalizing the mean union density of all occupations in the state-industry each year) while controlling for the effect of trends in the mean RTI of occupations in a state-industry on earnings. This helps to ensure that the effect of union density on returns to an occupation's RTI over time can be interpreted independent of changes in the composition of occupations within the industry. As shown in Table S3, the results are consistent with the primary analysis.

In the primary analysis, I include a pre/post-2003 dummy interacted with an occupation's RTI to ensure that the change in occupational coding in 2003 does not affect this study's results. As a sensitivity check, I also re-estimate the results on both the pre- and post- 
2003 samples (the 1983 to 2002 sample and the 2003 to 2017 sample). The results, presented in Table S2 in the Supplemental Appendix, show that the primary findings hold in both the segmented samples.

Finally, this study measures the effect of variation in union membership within stateindustries on earnings trends, but we could also look at the effect of variation in union membership between state-industries in a single year. A cross-sectional, multi-level model estimated in a single year is more capable of taking advantage of between-state variation in union coverage, but at the costs of increased likelihood of omitted variable bias and the loss of all time effects. Nonetheless, I present cross-sectional results of the effect of union coverage on earnings trends in Table S4. In line with this study's primary results, the cross-sectional models suggest that higher union coverage in a state-industry contributes to greater earnings returns to an occupation's RTI.

\section{DISCUSSION}

Routine-biased technological change (RBTC) has emerged as the dominant explanation for the decline in relative earnings of occupations at greater risk of automation. In contrast, this study draws on power resources theory and the comparative institutions literature to posit that the differential earnings trends of high routine task intensive (RTI) occupations can be largely attributed to the decline of organized labor. Placing the RBTC framework into politicalinstitutional context follows past research that has demonstrated how differences in labor market institutions directly affect the distribution of resources (Fernandez 2001, Kristal 2013). Rather than focusing on broader patterns of earnings inequality, however, this study narrows in on the earnings and employment penalties associated with an occupation's RTI - two empirical benchmarks that are central to the emergent literature on automation, routine work, and occupational polarization. 
Using micro-data spanning 3.3 million employed adults from 1983 to 2017, this study finds that higher levels of union coverage within a state and industry in the U.S. contribute to higher earnings growth for routine occupations. Thus, the observed decline of union coverage in the U.S. appears to have contributed to the period of occupational wage polarization in the 1990s, as well as the general decline in the earnings returns to an occupation's RTI. However, the relative earnings gains perhaps come at the cost of an accelerated decline in employment shares for routine occupations. I discuss these two countervailing effects - an earnings effect and employment share effect - in turn.

In prior literature related to RBTC, the decline in relative earnings growth among occupations at greater risk of automation is primarily attributed to exogenous forces shifting demand away from routine tasks. These past studies have been influential in shaping perceptions around the economic fate of middle-skill, middle-pay workers, yet tend to neglect contextual factors that might impede a straightforward relationship between technological change and variation in occupational earnings trends. Consistent with power resources theory and prior research on the union earnings premium, this study finds that the strength of organized labor shapes changes in the earnings distribution. More so, the findings show that organized labor is particularly consequential for the earnings trends of occupations at greater risk of automation. When unions are stronger within a state and industry, high RTI occupations experience greater relative earnings growth, all else equal. This is true even for non-unionized workers, consistent with results from Denice and Rosenfeld (2018). The counterfactual simulations show the magnitude of the results: had unionization remained stable from 1983 (an average of 26.2 percent), rather than dropping to an average of 13.7 percent by 2017 , the earnings returns to an occupation's RTI might not have declined between 1983 and 2017, rather than experiencing a steep decrease. Moreover, the period of occupational earnings polarization in the 1990s might not have occurred. The counterfactual results are robust, albeit with slightly 
weaker effects, when operationalizing union membership at the individual rather than stateindustry level (see Figure S1). These findings suggest that the RBTC framework, which attributes the declining relative earnings of routine occupations primarily to technological advancements, overlooks the importance of worker power in shaping the earnings trends of such occupations.

Despite the positive earnings effect, the evidence also points to a negative employment share effect of higher union membership. Consistent with prior evidence of organized labor inducing earnings-employments trade-offs, this study finds that higher union coverage within a state-industry can achieve higher relative earnings growth for automatable jobs, but at the cost of an accelerated decline in employment shares of automatable jobs. Had union coverage remained constant from 1983 to 2017, the mean RTI of occupations would have fallen by around 34 percent instead of 28 percent, a 6 percentage point (or 21 percent) steeper decrease than the observed decline.

These findings have direct implications on the emerging literature around automation and its consequences for labor markets and the income distribution. Most directly, they question the extent to which automation deserves credit for the declining relative earnings of routine occupations. Declining demand for routine tasks cannot, on its own, explain the observed decline in the earnings returns to an occupation's RTI in the U.S. from 1983 to 2000, or the lackluster earnings growth in among high RTI occupations from 2000 onward. Instead, this study makes clear that the decline of organized labor is a central source of the declining relative earnings growth of jobs at greater risk of automation. At the same time, organized labor may act to accelerate employment polarization, or the relative decline of high RTI occupation shares. This may help to explain why, as mentioned in this study's Introduction, many countries in the European Union (which tend to feature higher and more resilient levels of collective bargaining 
coverage than the U.S.) have experienced employment polarization without earnings polarization, though future research should investigate this in more detail.

Several limitations and opportunities for future research should be acknowledged. First, this study uses repeated cross-sections from the CPS MORG to understand how worker power shapes the relative earnings trends of routine occupations. Future work, however, would greatly benefit from the use of panel data, such as that available in the Panel Study of Income Dynamics, to assess whether the employment and earnings trajectories of routine occupations are conditional on union membership. This would allow for a more detailed investigation of the potential employment effects of union membership among routine occupations. Second, this study does not engage with the potential heterogeneous effects of union membership across different demographic profiles. Prior research shows, however, that unions have been particularly beneficial for the earnings of non-white workers (Rosenfeld 2014). It may thus be the case that the observed decline in relative earnings of routine occupations, spurred in part by declining worker power, contributes to greater racial inequality in earnings and poverty outcomes. Future work should investigate the implications of technological change on racial differences in economic opportunity in more detail. Third, this study does not assess whether unions, or other labor market institutions, attract or dispel greater investment into new technology. Future work should continue to improve our ability to measure technological change and to more explicitly measure whether greater worker power is a magnet or repellant for greater technological innovation.

In general, researchers should continue to place analyses of automation and occupational change into political-institutional context. As this study demonstrates, the social consequences of technological change appear to be conditional on the strength of organized labor. 


\section{REFERENCES}

Acemoglu, Daron. 2002. "Directed Technical Change." The Review of Economic Studies 69(4):781-809. doi: 10.1111/1467-937x.00226.

Acemoglu, Daron and David Autor. 2011. "Skills, Tasks and Technologies: Implications for Employment \& Earnings." Handbook of Labor Economics, Volume $4 b$.

Ahlquist, John S. and Margaret Levi. 2013. In the Interest of Others : Organizations and Social Activism. Princeton: Princeton University Press.

Antonczyk, Dirk, Thomas DeLeire and Bernd Fitzenberger. 2010. "Polarization and Rising Wage Inequality: Comparing the U.S. And Germany ". IZA Discussion Paper Series No. 4842.

Autor, David, Frank Levy and Richard J. Murnane. 2003. "The Skill Content of Recent Technological Change: An Empirical Exploration." Quarterly Journal of Economics, 118(4) (November 2003):1279-334.

Autor, David and David Dorn. 2013a. "The Growth of Low-Skill Service Jobs and the Polarization of the Us Labor Market." American Economic Review 2013(5):1553-97.

Autor, David H. and David Dorn. 2013b. "The Growth of Low-Skill Service Jobs and the Polarization of the Us Labor Market." American Economic Review 103(5):1553-97. doi: doi: 10.1257/aer.103.5.1553.

Biegert, Thomas. 2017. "Welfare Benefits and Unemployment in Affluent Democracies: The Moderating Role of the Institutional Insider/Outsider Divide." American Sociological Review 82(5):1037-64. doi: 10.1177/0003122417727095.

Böhm, Michael J. . 2017. "The Price of Polarization: Estimating Task Prices under RoutineBiased Technical Change." IZA (Institute for the Study of Labor) Discussion Paper Series (11220).

Brady, David. 2009. Rich Democracies, Poor People: How Politics Explain Poverty. Oxford: Oxford University Press.

Brady, David, R Baker and R Finnigan. 2013. "When Unionization Disappears: State-Level Unionization and Working Poverty in the United States." American Sociological Review 78(5):872-96. doi: 10.1177/0003122413501859.

Brady, David, Agnes Blome and Hannah Kleider. 2016. "How Politics and Institutions Shape Poverty and Inequality." in The Oxford Handbook of the Social Science of Poverty, edited by D. Brady and L. Burton. Oxford: Oxford University Press.

Brenke, Karl, Ulf Rinne and Klaus F. Zimmermann. 2011. "Short-Time Work: The German Answer to the Great Recession." IZA (Institute for the Study of Labor) Discussion Paper Series No. 5780.

Brueckner, Jan K. and David Neumark. 2014. "Beaches, Sunshine, and Public Sector Pay: Theory and Evidence on Amenities and Rent Extraction by Government Workers." American Economic Journal: Economic Policy 6(2):198-230. doi: 10.1257/pol.6.2.198.

Card, David, Francesco Devicienti and Agata Maida. 2014. "Rent-Sharing, Holdup, and Wages: Evidence from Matched Panel Data." The Review of Economic Studies 81(1):84-111. doi: 10.1093/restud/rdt030. 
Cardullo, Gabriele, Maurizio Conti and Giovanni Sulis. 2015. "Sunk Capital, Unions and the Hold-up Problem: Theory and Evidence from Cross-Country Sectoral Data."

European Economic Review 76:253-74. doi: https://doi.org/10.1016/j.euroecorev.2015.03.005.

Cortes, Guido Matias. 2016. "Where Have the Middle-Wage Workers Gone? A Study of Polarization Using Panel Data." Journal of Labor Economics 34(1):63-105.

Denice, Patrick and Jake Rosenfeld. 2018. "Unions and Nonuion Pay in the United States, 1977-2015." Sociological Science 5:541-61.

DiNardo, J., Nicole M. Fortin and Thomas Lemieux. 1996. "Labor Market Institutions and the Distribution of Wages, 1973-1992: A Semiparametric Approach." Econometrica 64(5):1001-44.

Dwyer, Rachel E. 2013. "The Care Economy? Gender, Economic Restructuring, and Job Polarization in the U.S. Labor Market." American Sociological Review 78(3):390-416. doi: 10.1177/0003122413487197.

Fernandez, Roberto M. 2001. "Skill-Biased Technological Change and Wage Inequality: Evidence from a Plant Retooling." American Journal of Sociology 107(2):273-320. doi: $10.1086 / 324009$.

Firpo, Sergio, Nicole M. Fortin and Thomas Lemieux. 2011. "Occupational Tasks and Changes in the Wage Structure." IZA (Institute for the Study of Labor) Discussion Paper Series (5542).

Goldin, Claudia Dale and Lawrence F. Katz. 2008. The Race between Education and Technology. Cambridge, Mass. ; London: Belknap.

Goos, Maarten, Alan Manning and Anna Salomons. 2009. "Job Polarization in Europe." American Economic Review: Papers \& Proceedings 99:2:58-63.

Goos, Maarten, Alan Manning and Anna Salomons. 2014. "Explaining Job Polarization: Routine-Biased Technological Change and Offshoring." American Economic Review 104(8):2509-26.

Hertel-Fernandez, Alexander. 2019. State Capture : How Conservative Activists, Big Businesses, and Wealthy Donors Reshaped the American States -- and the Nation. New York, NY: Oxford University Press.

Hirsch, B. T. and D. A. MacPherson. 2003. "Union Membership and Coverage Database from the Current Population Survey: Note." Industrial \& Labor Relations Review 56(2):349-54. doi: Doi 10.2307/3590942.

Hirsch, B. T. 2004. "What Do Unions Do for Economic Performance?". Journal of Labor Research 25:417-55.

Hirsch, Barry and Edward J. Schumacher. 2004. "Match Bias in Wage Gap Estimates Due to Earnings Imputation." Journal of Labor Economics 22(3):689-722.

Jacobs, David and Jonathan C. Dirlam. 2016. "Politics and Economic Stratification: Power Resources and Income Inequality in the United States." American Journal of Sociology 122(2):469-500. doi: 10.1086/687744.

Kalleberg, Arne L., Michael Wallace and Lawrence E. Raffalovich. 1984. "Accounting for Labors Share: Class and Income Distribution in the Printing Industry." Ilr Review 37(3):386-402. doi: 10.1177/001979398403700305. 
Katz, L. and David Autor. 1999. "Changes in the Wage Structure and Earnings Inequality." in Handbook of Labor Economics, Volume 3a, edited by O. Ashenfelter and D. Card. Amsterdam: Elsevier.

Katz, L. F. and K. M. Murphy. 1992. "Changes in Relative Wages, 1963-1987 - Supply-andDemand Factors." Quarterly Journal of Economics 107(1):35-78. doi: Doi $10.2307 / 2118323$.

Kimeldorf, Howard. 1992. "World War Ii and the Deradicalization of American Labor: The Ilwu as a Deviant Case." Labor History 33(2):248-78. doi: 10.1080/00236569200890121.

Korpi, Walter. 1983. The Democratic Class Struggle. London: Routledge \& Kegan Paul.

Korpi, Walter. 1985. "Action, Resources and Power - Causal and Final Explanatory Models in the Analysis of Power." Sociologisk Forskning 22(1):59-88.

Kristal, Tali. 2013. "The Capitalist Machine: Computerization, Workers' Power, and the Decline in Labor's Share within U.S. Industries." American Sociological Review 78(3):361-89. doi: 10.1177/0003122413481351.

Lemieux, Thomas. 2006. "Increasing Residual Wage Inequality: Composition Effects, Noisy Data, or Rising Demand for Skill?". American Economic Review 96(3):461-98. doi: 10.1257/aer.96.3.461.

Leonard, Jonathon. 1992. "Unions and Employment Growth." Industrial Relations: A Journal of Economy and Society 31(1):80-94. doi: 10.1111/j.1468-232X.1992.tb00299.x.

Lindbeck, Assar and Dennis J. Snower. 2001. "Insiders Versus Outsiders." The Journal of Economic Perspectives 15(1):165-88.

Lordan, Grace and David Neumark. 2017. "People Versus Machines: The Impact of Minimum Wages on Automatable Jobs." National Bureau of Economic Research Working Paper Series No. 23667. doi: 10.3386/w23667.

Mahutga, Matthew C., Michaela Curran and Anthony Roberts. 2018. "Job Tasks and the Comparative Structure of Income and Employment: Routine Task Intensity and Offshorability for the Lis." International Journal of Comparative Sociology 59(2):81109.

Mishel, Lawrence, John Schmitt and Heidi Shierholz. 2013. "Assessing the Job Polarization Explanation of Growing Wage Inequality." Economic Policy Institute Working Paper \#295.

Naticchioni, Paolo, Giuseppe Ragusa and Riccardo Massari. 2014. "Unconditional and Conditional Wage Polarization in Europe." IZA Discussion Paper Series No. 8456.

Newman, Robert J. 1983. "Industry Migration and Growth in the South." The Review of Economics and Statistics 65(1):76-86. doi: 10.2307/1924411.

Nickell, S. J. and M. Andrews. 1983. "Unions, Real Wages and Employment in Britain 195179." Oxford Economic Papers 35:183-206.

OECD. 2011. Divided We Stand: Why Inequality Keeps Rising. Paris: OECD.

OECD. 2017. Oecd Employment Outlook 2017: OECD Publishing.

Pencavel, John H. 1984. "The Tradeoff between Wages and Employment in Trade Union Objectives*." The Quarterly Journal of Economics 99(2):215-31. doi:

$10.2307 / 1885523$. 
Rosenfeld, Jake. 2014. What Unions No Longer Do. Cambridge, Massachusetts: Harvard University Press.

Thelen, K. 2015. "Varieties of Liberalization and the New Politics of Social Solidarity (Vol 68, Pg 710, 2015)." Ilr Review 68(4):970-70. doi: 10.1177/0019793915595009.

VanHeuvelen, Tom. 2018. "Moral Economies or Hidden Talents? A Longitudinal Analysis of Union Decline and Wage Inequality, 1973-2015." Social Forces 97(2):495-530. doi: 10.1093/sf/soy045.

Visser, Jelle and Daniele Checchi. 2011. "Inequality and the Labour Market: Unions." The Oxford Handbook of Economic Inequality.

Western, Bruce and Jake Rosenfeld. 2011. "Unions, Norms, and the Rise in U.S. Wage Inequality." American Sociological Review 76(4):513-37. doi: 10.1177/0003122411414817.

Wilmers, Nathan. 2017. "Labor Unions as Activist Organizations: A Union Power Approach to Estimating Union Wage Effects." Social Forces 95(4):1451-78. doi: 10.1093/sf/sow108. 
APPENDIX A: Calculating the Routine Task Intensity (RTI) Index

Using information on job tasks from the Occupational Information Network database (O*NET), the RTI index assigns values to occupations according to the extent to which they require routine, manual, or abstract tasks. Specifically, Acemoglu and Autor (2011) compute an occupation's RTI as follows:

$$
R T I_{k}=\ln \left(T_{k}^{R}\right)-\ln \left(T_{k}^{M}\right)-\ln \left(T_{k}^{A}\right)
$$

where $T_{k}^{R}, T_{k}^{M}$, and $T_{k}^{A}$ represent, respectively, the level of routine, manual, and abstract task inputs for an occupation $k$. Routine tasks consist of repeated sequence of actions and are more easily replaceable through technological innovations. Manual tasks, meanwhile, do not generally follow a predictable sequence and therefore are more resistant to automation. Abstract tasks tend to complement new technologies rather than to be automated. Given this equation, a higher value of $R T I_{k}$ indicates that an occupation is more 'routine-task intensive' and, thus, can more readily be automated. 
APPENDIX B: Descriptive Statistics

\begin{tabular}{lrrrr}
\hline Variable & Mean & St. Dev & Min. & Max. \\
\hline State-Industry-Year Union Membership & 0.17 & 0.14 & 0.00 & 0.68 \\
Female & 0.46 & 0.50 & 0 & 1 \\
Age & 39.2 & 11.6 & 18 & 65 \\
Education: Low (HS Degree) & 0.44 & 0.50 & 0 & 1 \\
Education: High (College Degree) & 0.30 & 0.46 & 0 & 1 \\
Race/Eth.: White & 0.86 & 0.35 & 0 & 1 \\
Race/Eth.: Black & 0.09 & 0.28 & 0 & 1 \\
Race/Eth.: Other & 0.04 & 0.19 & 0 & 1 \\
Race/Eth.: Hisp & 0.09 & 0.29 & 0 & 1 \\
Married & 0.61 & 0.48 & 0 & 1 \\
City Center & 0.23 & 0.42 & 0 & 1 \\
Routine Task Intensity (scaled zero to one) & 0.33 & 0.19 & 0 & 1 \\
\hline
\end{tabular}




\title{
ENDNOTES
}

\begin{abstract}
${ }^{1}$ Advanced technologies tend to benefit owners of capital and high-skill workers which, combined with increased consumption of goods and services among higher-paid workers, is theorized to contribute to a rise of employment shares among low-skill occupations, typically in the services sector (Autor, 2015). Some scholars, however, disagree on the extent to which advancements in technology deserve credit for employment polarization (Salvatori, 2015). ${ }^{2}$ Company data show that Hyundai operates a plant in Alabama; Nissan operates plants in Mississippi and Tennessee; and Toyota operates plants in Kentucky, Texas, Mississippi,
\end{abstract} Alabama, and Indiana.

${ }^{3}$ One challenge in measuring the association between union membership and investments into new technology is the lack of a comprehensive measure of technological investment at the state and industry level. The routine task intensity approach, as adopted in this paper, is recognized as "the best way to capture the impact of recent technological progress" (Goos, Manning, and Salomons, 2014: 2511). However, detailed state-industry level data on firm investments into ICT would be beneficial in investigating this relationship moving forward. ${ }^{4}$ Results are consistent when standard errors are clustered on both occupation and state. ${ }^{5}$ The inclusion of state-year-industry fixed effects accounts for other time-varying institutional factors at the state-industry level that affect the relationship between union membership and earnings of routine occupations. Nonetheless, this study cannot rule out the possibility that changes in state-industry union membership are closely correlated with changes in other state-industry characteristics. 